\title{
Preparation and Rheological Characterization of Imogolite Hydrogels
}

\author{
Kie Fujikura, ${ }^{1}$ Hirotaka Maeda, ${ }^{2}$ Akiko Obata, ${ }^{1}$ Keiichi Inukai, ${ }^{3}$ \\ Katsuya Kato, ${ }^{3}$ and Toshihiro Kasuga ${ }^{1}$ \\ ${ }^{1}$ Graduate School of Engineering, Nagoya Institute of Technology, Gokiso-cho, Showa-ku, Nagoya 466-8555, Japan \\ ${ }^{2}$ Center for Fostering Young and Innovative Researchers, Nagoya Institute of Technology, Japan \\ ${ }^{3}$ National Institute of Advanced Industrial Science and Technology, Japan \\ Correspondence should be addressed to Toshihiro Kasuga; kasuga.toshihiro@nitech.ac.jp
}

Received 28 March 2014; Revised 13 July 2014; Accepted 13 July 2014; Published 23 July 2014

Academic Editor: Abdelwahab Omri

Copyright (C) 2014 Kie Fujikura et al. This is an open access article distributed under the Creative Commons Attribution License, which permits unrestricted use, distribution, and reproduction in any medium, provided the original work is properly cited.

\begin{abstract}
Imogolite, one of the aluminium silicates, has a nanotube structure and has been known to form gel under alkaline condition. Imogolite nanotubes were synthesized in an acidic solution with various tube lengths by controlling the aging time from $1 \mathrm{~d}$ to $14 \mathrm{~d}$. The length of the nanotubes grew from $100 \mathrm{~nm}$ to several $\mu \mathrm{m}$ as the aging time. Pure imogolite hydrogels were prepared by applying a salting-out method and centrifugation from its dispersed solutions with various tube lengths and solution $\mathrm{pH}$. Imogolite hydrogel can be classified as the physically cross-linked one; the structure of the gel network is considered to be the entanglements and hydrogen bonding among nanotubes. The theoretical water contents of the prepared hydrogels were calculated as $\sim 99.7 \%$ in average. Gelation percentage significantly increased as the length of imogolite nanotubes. Whereas hydrogel prepared from $4 \mathrm{~d}$ aging sample showed the highest storage modulus of $\sim 970 \mathrm{~Pa}$, it was found that the hydrogel could be prepared in the $\mathrm{pH}$ range from 6 to 10. The gel strength reached the highest value of $1000 \mathrm{~Pa}$ when the gel was prepared from the imogolite dispersed solution of $\mathrm{pH}$ 8. It could be explained by the surface charge variation of the imogolite.
\end{abstract}

\section{Introduction}

Imogolite is a nanosized tubular aluminium silicate with a chemical composition of $\mathrm{SiO}_{2} \cdot \mathrm{Al}_{2} \mathrm{O}_{3} \cdot 2 \mathrm{H}_{2} \mathrm{O}$. It is found in volcanic soil and has been researched in the field of clay minerals and soil science. Its structure and surface chemistry have been studied and described by Cradwick et al. $[1,2]$. The imogolite tube has a wall composed of single continuous sheet with gibbsite-like structure, with considerable numbers of hydroxyl groups on both inner and outer surface. The typical inner and outer diameters of the tube are $1.0 \mathrm{~nm}$ and 2.0 $2.7 \mathrm{~nm}$, respectively.

Synthesis procedure of the imogolite has been investigated by many researchers and, recently, one of the simple procedures has been successfully established [3-8]. According to the synthesis method established by Suzuki et al. [8], imogolite can be obtained with highly dispersed state in acidic solution. The imogolite in a dispersed solution shows unique properties such as flocculation behavior depending on $\mathrm{pH}$ or its concentration of the solution. It has been reported that imogolite dispersed solution form jelly-like substance (hydrogel) on alkalization with ammonia aq. This transparent gel formation is employed as the method of confirmation in imogolite synthesis as well as the turbidity measurement, since other by-products such as allophane do not form the gel $[8,9]$.

Hydrogels are quite attractive materials for various applications, especially in the biomedical field, since they are able to be injected into a defect site and to deliver medicines with a minimum operation [10-12]. Hydrogels are regarded to be able to serve as a suitable vehicle for a local delivery of appropriate growth factors and/or cells to facilitate tissue regeneration [13]. Another idea of its application is the supporting material for powder or granule bone substitutes as vehicles. It would help to improve the operation performance. In both ways, it would be best to contain minimum gel forming material; in other words, the high water content is the best for loading elements. 
Now, it is possible to produce imogolite nanotubes constantly in high purity with a safe and simple method, the imogolite is considered to be one of the promising materials for use in the biomaterials field. Recently, some researches on the imogolite aimed at applications for biomaterials have been published. Ishikawa et al. investigated the cellular responses of osteoblast-like cells on the imogolite scaffold and revealed that the cells showed good compatibility and enhanced mineralization $[14,15]$. Some other groups have been researched on the preparation of the hybrid or composite gel with polymers. Yamamoto et al. have studied the preparation of the imogolite-poly(vinyl alcohol) composite and hybrid. In their report, the mechanical and thermal properties of the PVA film have been improved [16]. Also, they have attempted to prepare the hybrid gel consisting of pepsin and imogolite [17]. As for natural biopolymers, collagen or DNA has been studied to prepare the complex gel with imogolite $[18,19]$.

Although imogolite attracts attention as one of the nanofibrous materials, its gel formation has been known as just a phenomenon. There are almost no reports focusing on the preparation of pure imogolite gel and its characterization. The viscoelasticity is one of the important parameters to characterize the properties of gels. Measured values of storage modulus $G^{\prime}$ and loss modulus $G^{\prime \prime}$ reflect solid and liquid characters of the gel sample, respectively; thus rheometer is one of the most appropriate measurement tools to understand the characteristics of the gel.

In the present work, imogolite hydrogels were prepared from their dispersed solution and the rheological properties were characterized. The effects of the length of the nanotubes or $\mathrm{pH}$ of the dispersed solution on gel formation and properties were examined. Since imogolite, which is used in this work, has been synthesized in the acidic solution, it was possible to control the tube length of the imogolite by aging time of the solution. The tube length may affect the biological functions such as cellular responses due to its surface area. The $\mathrm{pH}$ level of the material is one of the most important parameters when it would be applied to biomaterials.

\section{Materials and Methods}

2.1. Preparation of Imogolite Dispersed Solution. Imogolite was prepared, following previous reports by Suzuki et al. [6, 8]. An aluminium chloride solution and a sodium orthosilicate solution were prepared by dissolving reagent grade of $\mathrm{AlCl}_{3} \cdot 6 \mathrm{H}_{2} \mathrm{O}$ and $\mathrm{Na}_{4} \mathrm{SiO}_{4}$ (Wako Pure Chemical Industries Ltd.) in deionized water, respectively. $\mathrm{Na}_{4} \mathrm{SiO}_{4}$ aq was instantaneously added into $\mathrm{AlCl}_{3}$ aq with vigorous stirring. The ratio $\mathrm{Si} / \mathrm{Al}$ of resulting solution was 0.41 . To this solution, $1 \mathrm{M}-\mathrm{NaOH}$ was added at a rate of $2 \mathrm{~mL} / \mathrm{min}$ until the $\mathrm{pH}$ of the solution reached 6.8 . In order to desalinate, the solution was centrifuged. The precipitate was separated and dispersed again by adding deionized water. The final dispersed solution was adjusted to $\mathrm{pH}$ below 4 with $\mathrm{HCl}$. The solutions were aged at $95^{\circ} \mathrm{C}$ for 1,4 , and $14 \mathrm{~d}$, respectively. Some portions from each solution were oven-dried to measure the concentration of imogolite. All of the solutions contained approximately $0.07 \mathrm{wt} \%$ of imogolite.
2.2. Observation of the Imogolite Nanotubes and Measurement of Tube Lengths. In order to examine the synthesized imogolite, an atomic force microscopy (AFM; NanoScope IIIa, Bruker AXS) was carried out. Samples for AFM measurement were prepared on the cleavage surface of mica using a thousandfold diluted imogolite dispersed solutions.

2.3. Gelation and Measurement of Gel Volume. In order to obtain the pure imogolite hydrogel from its dispersed solution, a salting-out method was employed. The $\mathrm{pH}$ of the synthesized imogolite solution was adjusted around 6.8 for tube length varied samples (samples code: $1 \mathrm{~d}, 4 \mathrm{~d}$, and $14 \mathrm{~d}$ ) or 4.0-10 for $\mathrm{pH}$ varied samples (samples code: $\mathrm{pH} 4,5,6$, $7,8,9$, and 10 ) by dropping $0.1 \mathrm{M}-\mathrm{NaOH}$. A portion of the $\mathrm{pH}$-adjusted sol was placed in a centrifuge tube and $1 \mathrm{M}-\mathrm{NaCl}$ was added. The solution was mixed gently and left for $1 \mathrm{~h}$. After the gelation, the solution was centrifuged for $10 \mathrm{~min}$ at $3000 \mathrm{rpm}$. The supernatant liquid was decanted off and the weight of remaining precipitate was measured. The gel state was confirmed by inverting the test tubes. A fraction of the weights of the gel and the initial solution was calculated as a gelation rate by

$$
\begin{aligned}
& \text { Gelation (\%) } \\
& =\frac{\text { Remained gel weight }[\mathrm{g}]}{\text { Initial imogolite disparsed solution weight }[\mathrm{g}]} \times 100 \text {. }
\end{aligned}
$$

2.4. Rheological Characterizations. The rheological properties of the imogolite gel samples were examined using a rheometer (MCR101, Anton Peer, Japan). The parallel plate measuring system with a $25 \mathrm{~mm}$ in diameter plate geometry was applied and the distance between the measuring plates (the gap distance) was set to $1 \mathrm{~mm}$. During all measurements, a constant temperature at $37^{\circ} \mathrm{C}$ was given regulated by a Peltier unit. The storage modulus $\left(G^{\prime}\right)$ and loss modulus $\left(G^{\prime \prime}\right)$ were measured at various strain amplitudes at a frequency $f=1 \mathrm{~Hz}$. In addition, the frequency dependence of both moduli of the samples was measured from 0.1 to $10.0 \mathrm{~Hz}$ under the strain of $1 \%$.

\section{Results and Discussion}

3.1. AFM Observation. Figure 1 shows AFM images of the synthesized imogolite with various heating durations and histograms of their tube length distributions. It is clearly seen from the images that the tube length of the imogolite grows with the heating duration. From the distribution figure, the most of the tubes in sample $1 \mathrm{~d}$ had lengths of less than $500 \mathrm{~nm}$. After $4 \mathrm{~d}$ of heating, imogolite tubes with more than $1 \mu \mathrm{m}$ appeared. After $14 \mathrm{~d}$ of heating, longer tubes with more than $2 \mu \mathrm{m}$ in length appeared and the number of the short tubes decreased. Average tube lengths of $1 \mathrm{~d}, 4 \mathrm{~d}$, and $14 \mathrm{~d}$ aged imogolites were $\sim 160 \pm 70 \mathrm{~nm}, \sim 390 \pm 320 \mathrm{~nm}$, and $\sim 530 \pm$ $480 \mathrm{~nm}$, respectively. 


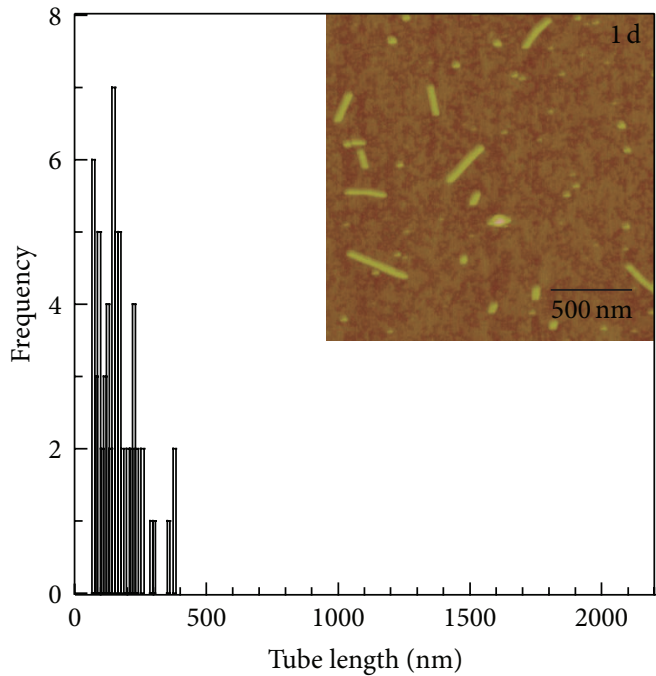

(a)

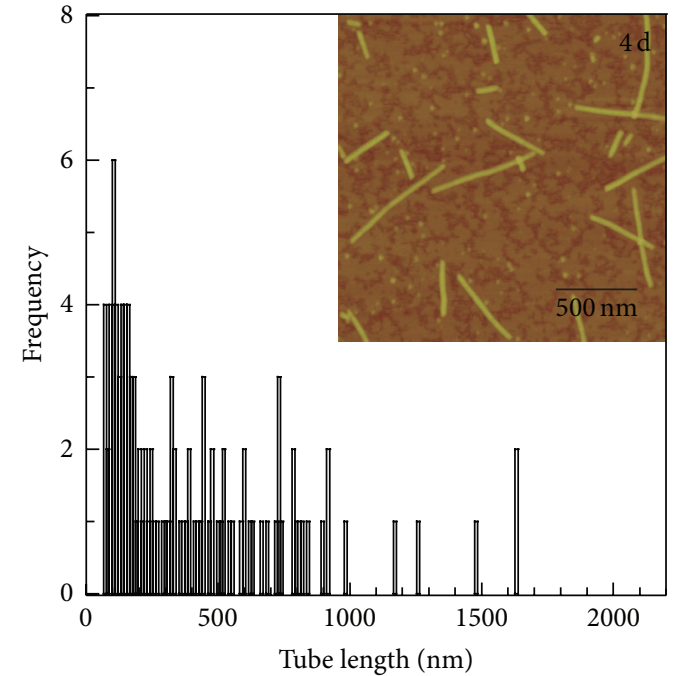

(b)

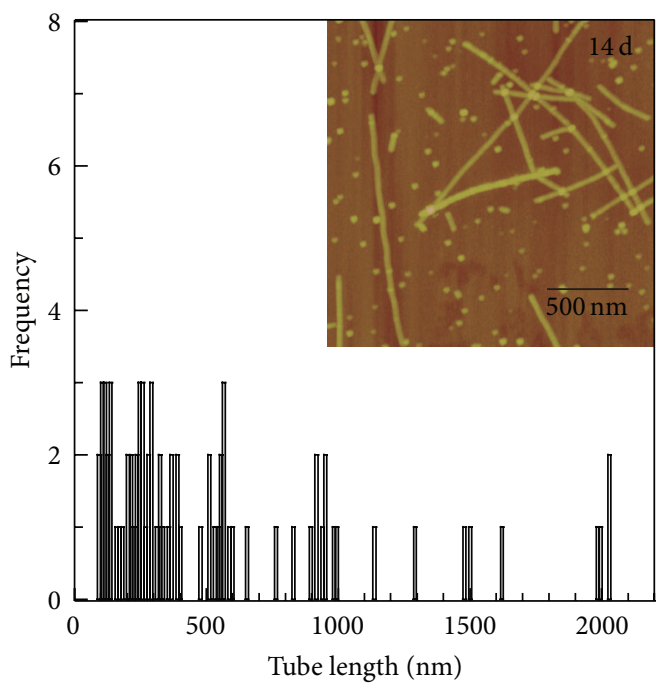

(c)

FIGURE 1: AFM images of the synthesized imogolites with various heating duration and histograms of the tube length distribution.

3.2. Gelation. Figure 2 shows an appearance of a typical imogolite gel at the bottom of a centrifuge tube. All gels were visually transparent. The imogolite hydrogel was prepared by the salting-out method and centrifugation; otherwise it is difficult to obtain such a transparent, high-water content hydrogel. It is because that once the imogolite gets dry, the nanotubes aggregate too tightly to redisperse. The gelation rates (gel weight) of the imogolite gels prepared from their dispersed solution with various tube lengths were shown in Figure 3. Gelation rate dramatically increased between $4 \mathrm{~d}$ and $14 \mathrm{~d}$ samples. It is considered that the longer the lengths of the nanotubes are, the larger the spaces where water is held could be. The $14 \mathrm{~d}$ sample formed gel containing almost all of the liquid; however, it was quite unstable as it easily releases the water when it is taken out from the centrifuge tube.

The gelation rate of the gel samples prepared from various $\mathrm{pH}$ of the dispersed solutions is summarized in Figure 4.
In case of the solution with $\mathrm{pH} 4$ or 5 , it seemed that the sample solutions partially formed gel, but they were unstable and it was difficult to separate the gel from the supernatant by the centrifugal method with the current condition. There was almost no gel remaining after inverting the tube. If the $\mathrm{pH}$ values of the solutions are over 6 , the gel moiety formed within the solution could be successfully separated by the centrifugal step and about $20 \%$ of the total solution could be constantly collected as the hydrogel. Based on the imogolite concentration of its dispersed solution, the water concentrations were calculated as $\sim 99.7 \%$ in average.

According to the International Union of Pure and Applied Chemistry (IUPAC), a definition of the gel is as follows: nonfluid colloidal network or polymer network, that is, expanded throughout its whole volume by a fluid [20]. So a hydrogel has a structure of a three-dimensional network consisting of colloidal particles or macromolecular chains, in 
TABLE 1: Summarized results of rheological characterization: values of the deformation limit $\left(\gamma_{L}\right)$ and yield stress $\left(\tau_{y}\right)$, cross over point of $G^{\prime}$ and $G^{\prime \prime}$, and gel strength $\left(\left|G^{\prime}\right|\right)$.

\begin{tabular}{lcccc}
\hline Sample & Deformation limit $\left(\gamma_{L}\right)(\%)$ & Yield stress $\left(\tau_{y}\right) / \mathrm{Pa}$ & Crossover point $(\%)$ & $\left|G^{\prime}\right|$ at $f=1 \mathrm{~Hz} / \mathrm{Pa}$ \\
\hline 1 d & 4.64 & 5.66 & 33.2 & 124 \\
$4 \mathrm{~d}$ & 10.0 & 101 & 51.4 & 969 \\
$14 \mathrm{~d}$ & 14.7 & 32.3 & 4.7 & 104 \\
pH 6 & 15.8 & 24.5 & 28.2 & 521 \\
pH 7 & 10.0 & 71.2 & 34.1 & 991 \\
pH 8 & 12.6 & 105 & 75.4 & 999 \\
pH 9 & 12.6 & 24.0 & 100 & 288 \\
pH 10 & 20.0 & 24.8 & & 129 \\
\hline
\end{tabular}

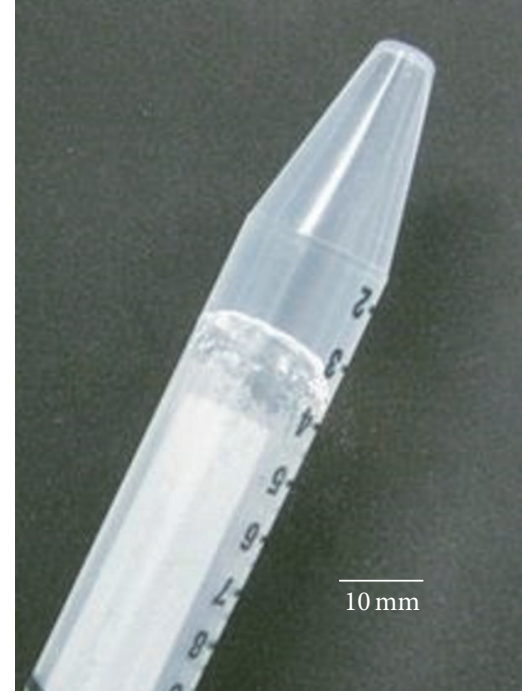

FIGURE 2: An appearance of the obtained imogolite hydrogel.

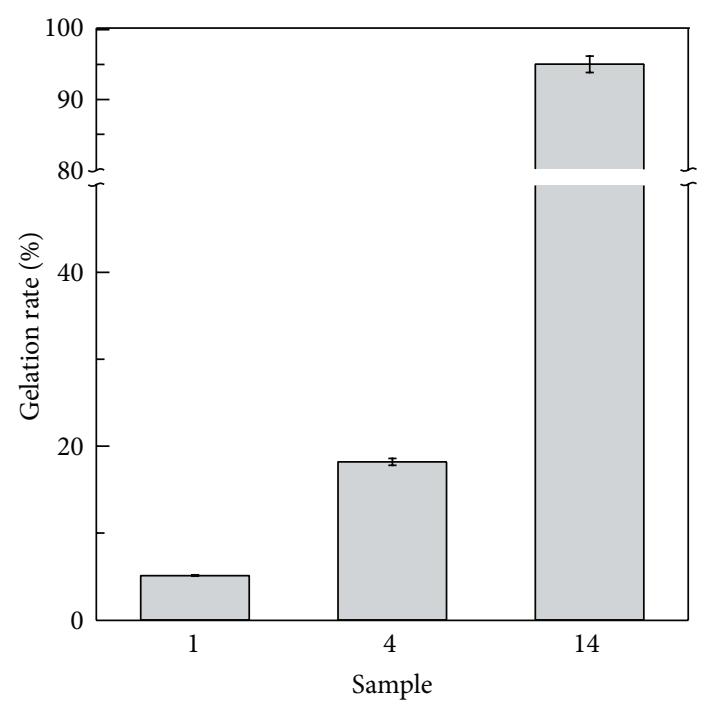

FIGURE 3: Gelation rates of the samples prepared with various tube lengths.

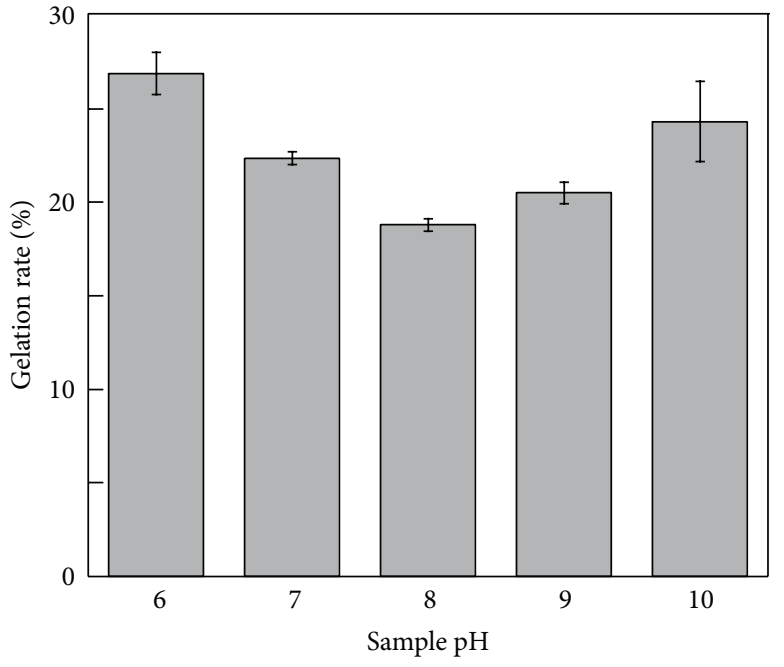

FIGURE 4: Gelation rates of imogolite gels prepared with various $\mathrm{pH}$ of imogolite dispersed solutions. The numbers on the $x$-axis represent $\mathrm{pH}$ values of prepared samples.

which water is dispersed and held. In case of the imogolite hydrogel, the network is considered to be made up by the entanglement and hydrogen bonding among the imogolite nanotubes. Since the current imogolite gel has been prepared from its dispersed state, it was possible to retain a large amount of water within the spaces among the imogolite nanotubes, which have the considerable numbers of hydroxyl groups on the surfaces. The current gel can be classified as the physically cross-linked hydrogel, which has potential of thixotropic behavior.

3.3. Rheological Characterization. In order to quantify and investigate the flow behavior and gel properties of the imogolite gel, stress sweep and frequency sweep tests were performed [21]. Parameters and specific characteristics as a deformation limit $\left(\gamma_{L}\right)$, yield stress $\left(\tau_{y}\right)$, a crossover point of storage $\left(G^{\prime}\right)$ and loss moduli $\left(G^{\prime \prime}\right)$ from stress-strain relationship, and gel strength in terms of $G^{\prime}$ from frequency sweep measurement were determined. Those values of the samples were summarized in Table 1. 


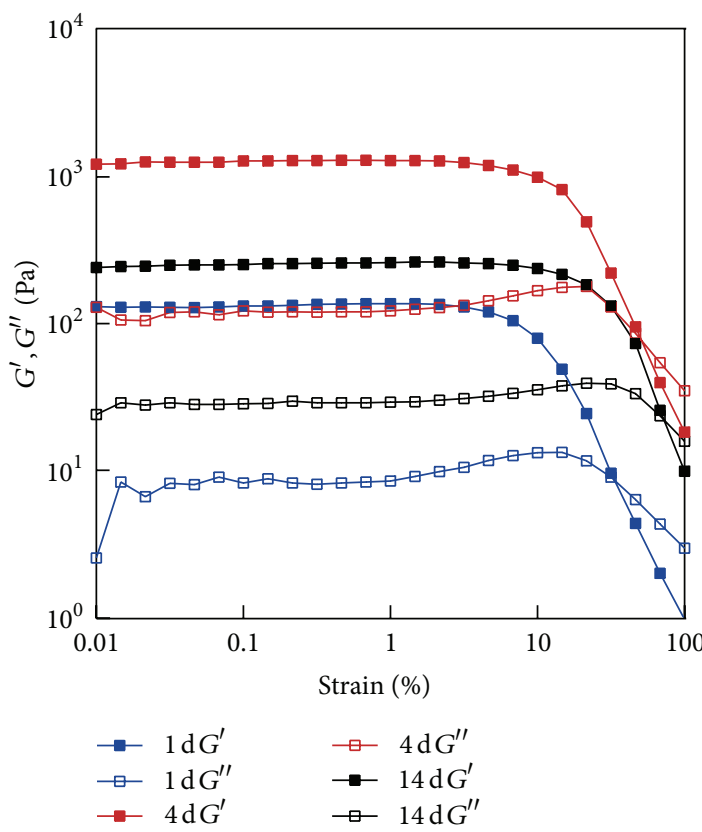

(a)

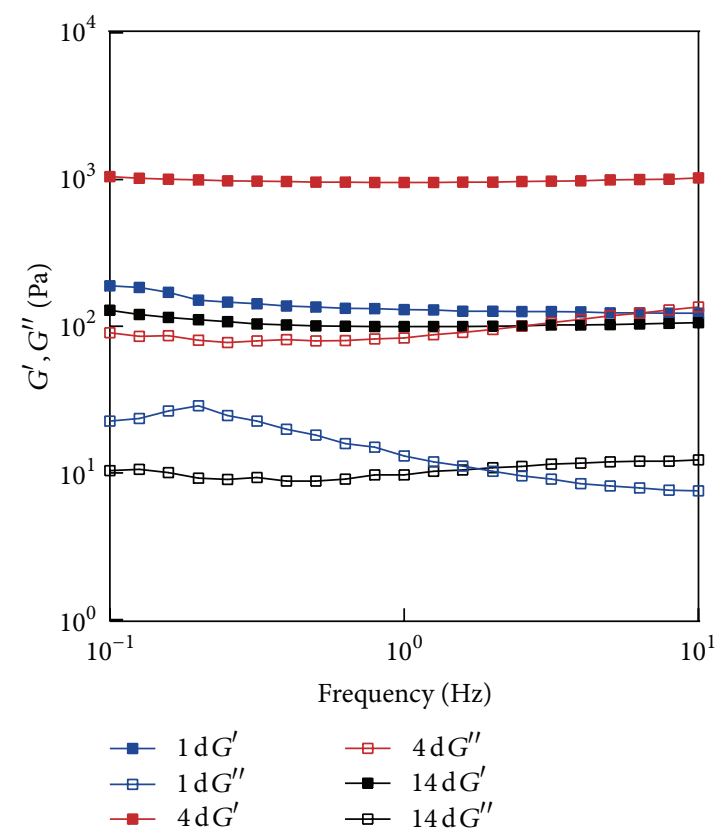

(b)

Figure 5: Typical results of (a) strain sweep test and (b) frequency sweep measurement on the samples with different tube lengths.

Figure 5(a) shows the storage $\left(G^{\prime}\right)$ and loss $\left(G^{\prime \prime}\right)$ moduli of the imogolite hydrogels with various tube lengths as a function of shear strain amplitude $\gamma$ from 0.01 to $100 \%$. The linear viscoelasticity (LVE) range was observed approximately until $\gamma<5,10$, and 15\% and the crossover of $G^{\prime}$ and $G^{\prime \prime}$ happened at $\gamma=33,51,72 \%$ for samples $1 \mathrm{~d}, 4 \mathrm{~d}$, and $14 \mathrm{~d}$, respectively. The frequency dependence of dynamic viscoelasticity of the imogolite hydrogel with various tube lengths is shown in Figure 5(b). Both moduli showed plateau regions in all samples throughout the frequency range. It is considered that the gel consisting of longer nanotubes showed more viscous character and could follow the applied strain so that the strain of the deformation limit increased. Whereas the applied stress at the deformation point, that is, yield stress, reflected the strength of the gel, the values of $G^{\prime}$, which are considered as an indicator of strength of the gel, did not show the tube length dependence. The $4 \mathrm{~d}$ sample showed the highest storage modulus of $970 \mathrm{~Pa}$, which is a magnitude higher $G^{\prime}$ than that of $1 \mathrm{~d}$ or $14 \mathrm{~d}$, about $120 \mathrm{~Pa}$ and $100 \mathrm{~Pa}$, respectively. The gel strength of the $14 \mathrm{~d}$ sample was lower than that of $4 \mathrm{~d}$ one, because the spaces among the imogolite tubes in the $14 \mathrm{~d}$ sample are considered to be too large to retain the water. Although a large amount of water is retained among the large space, the stability of the gel is not strong due to the weakness of the network connection, that is, hydrogen bonding. It was actually unstable as mentioned earlier and seems difficult to show appropriate handling performance. A peptide gel with storage modulus of $\sim 480 \mathrm{~Pa}$ has been reported to have good injectability [22]. The tube length of $4 \mathrm{~d}$ sample is believed to be optimum for the preparation of imogolite hydrogels.

Using the dispersed solution of $4 \mathrm{~d}$ aged imogolite, various $\mathrm{pH}$-adjusted solutions were prepared by adding

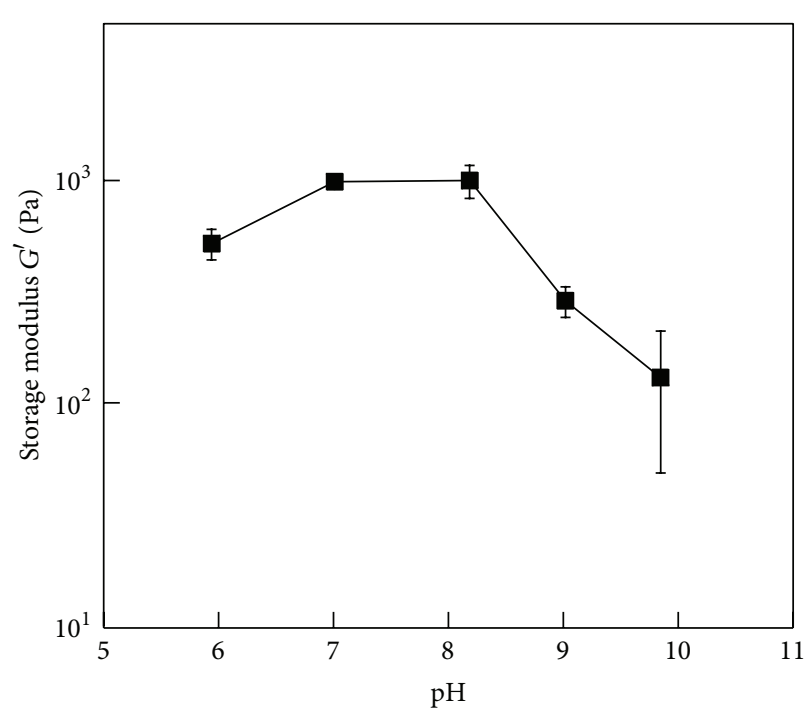

FIGURE 6: $\mathrm{pH}$ dependence of gel strength and strain at the deformation point of samples.

$\mathrm{NaOH} a q$ and their rheological characterization was conducted. Figure 6 shows the $\mathrm{pH}$ dependence of the viscoelastic behavior of the imogolite hydrogels. The measured storage modulus at a frequency of $1 \mathrm{~Hz}$ was plotted against $\mathrm{pH}$ of each imogolite gel. The storage modulus reached the highest value of approximately $1000 \mathrm{~Pa}$ at the $\mathrm{pH} 8$ and then decreased significantly with increasing $\mathrm{pH}$.

It could be explained by the surface charge variation and the electrophoretic behavior of the imogolite nanotubes. It has been reported that the surface charge of the imogolite 
tubes changes from positive to negative depending on $\mathrm{pH}$ level. In the acidic environment, outer surfaces of the imogolite nanotubes are positively charged so that they repel each other and dispersed well. The isoelectric point of natural imogolite has been reported to be around $\mathrm{pH} 7$ [23]. That is, the surface charge and mobility of imogolite nanotubes become zero. At this point, since the salting-out method has been applied in the current experiment, the added electrolyte put imogolite tubes close to each other and make them form hydrogen bonding resulting in the formation of the hydrogel. In the alkaline $\mathrm{pH}$ range, it is considered that generation of the negative charges at the inside of imogolite wall occurs [24]. The decrease of the storage modulus of the gel at $\mathrm{pH}$ 9-10 could be explained by this regeneration of weak electrostatistic repulsion at the edges of the imogolite nanotubes. It is revealed that the surface charges variation of the imogolite nanotubes may reflect the gel strength of the imogolite hydrogel.

\section{Conclusion}

In the present work, an inorganic hydrogel consisting of imogolite nanotubes has been prepared and its rheological properties were characterized. One of the extremely highwater content hydrogel preparation methods from imogolite dispersed solution has been successfully established. By applying a salting-out method, the gel substances were constantly obtained from the dispersed solution at $\mathrm{pH}$ range from 6 to 10 after centrifuging. The hydrogel could be prepared for the first time at almost neutral $\mathrm{pH}$ to our best knowledge. The gel strength reached the highest value when the gel was prepared from the $4 \mathrm{~d}$ imogolite (average tube length of $~$ $390 \mathrm{~nm}$ ) and its solution of $\mathrm{pH}$ 8. It was revealed that the gel strength is affected by $\mathrm{pH}$ of the solution due to the surface charge variation of the nanotubes. This work is regarded as a part of the fundamental study of the characteristic of imogolite gel. It is expected that those findings about imogolite would break ground for its biomedical application.

\section{Conflict of Interests}

None of the authors have any conflict of interests associated with the current paper.

\section{Acknowledgment}

This work was supported in part by Grant-in-Aid for JSPS Fellows no. 24.9916 and Grant-in-Aid for Exploratory Research no. 25630282 .

\section{References}

[1] P. Cradwick, V. Farmer, J. Russell, C. Masson, K. Wada, and N. Yoshinaga, "Imogolite, a hydrated aluminium silicate of tubular structure," Nature, vol. 240, no. 104, pp. 187-189, 1972.

[2] K. Wada, N. Yoshinaga, and K. Yotsumoto, "High resolution electron micrographs of imogolite," Clay Mineralogy, vol. 8, no. 4, pp. 487-489, 1970.
[3] K. Wada and T. Henmi, "Characterization of micropores of imogolite by measuring retention of quaternary ammonium chlorides and water," Clay Science, vol. 4, no. 3, pp. 127-136, 1972.

[4] V. C. Farmer, A. R. Fraser, and J. M. Tait, "Synthesis of imogolite: a tubular aluminium silicate polymer," Journal of the Chemical Society, Chemical Communications, no. 13, pp. 462-463, 1977.

[5] S. Wada, A. Eto, and K. Wada, "Synthetic allophane and imogolite," Journal of Soil Science, vol. 30, no. 2, pp. 347-355, 1979.

[6] M. Suzuki, F. Ohashi, K. Inukai, M. Maeda, and S. Tomura, "Synthesis of allophane and imogolite from inorganic solution," Nendo Kagaku, vol. 40, no. 1, pp. 1-14, 2000.

[7] M. Suzuki, K. Inukai, and M. Maeda, "Synthesis of imogolite from inorganic solution-influence of solution concentration on forming precursor for the synthesis of large quantities of imogolite," Journal of the Vacuum Society of Japan, vol. 49, no. 1, pp. 29-33, 2006.

[8] M. Suzuki, H. Sato, C. Ikeda, R. Nakanishi, K. Inukai, and M. Maeda, "State change of imogolite according to heating duration on synthesizing," Nendo Kagaku, vol. 46, no. 4, pp. 194199, 2007.

[9] S. Wada and C. Sakimura, "Effect of calcium, sodium and chloride ions on the growth of imogolite tubes as measued by gel forming property," Clay Science, vol. 11, no. 2, pp. 115-123, 2000.

[10] Q. Hou, P. A. De Bank, and K. M. Shakesheff, "Injectable scaffolds for tissue regeneration," Journal of Materials Chemistry, vol. 14, no. 13, pp. 1915-1923, 2004.

[11] P. P. Kalshetti, V. B. Rajendra, D. N. Dixit, and P. P. Parekh, "Hydrogels as a drug delivery system and applications: a review," International Journal of Pharmacy and Pharmaceutical Sciences, vol. 4, no. 1, pp. 1-7, 2012.

[12] K. Lee, E. A. Silva, and D. J. Mooney, "Growth factor deliverybased tissue engineering: general approaches and a review of recent developments," Journal of the Royal Society Interface, vol. 8, no. 55, pp. 153-170, 2011.

[13] A. A. Amini and L. S. Nair, "Injectable hydrogels for bone and cartilage repair," Biomedical Materials, vol. 7, no. 2, Article ID 024105, 2012.

[14] K. Ishikawa, S. Abe, Y. Yawaka, M. Suzuki, and F. Watari, "Osteoblastic cellular responses to aluminosilicate nanotubes, imogolite using Saos-2 and MC3T3-E1 cells," Journal of the Ceramic Society of Japan, vol. 118, no. 1378, pp. 516-520, 2010.

[15] K. Ishikawa, T. Akasaka, Y. Nodasaka et al., "Physical properties of aluminosilicate nanotubes, imogolite, as scaffold and effect on osteoblastic mineralization," Nano Biomedicine, vol. 1, no. 2, pp. 109-120, 2009.

[16] K. Yamamoto, H. Otsuka, S. Wada, D. Sohn, and A. Takahara, "Transparent polymer nanohybrid prepared by in situ synthesis of aluminosilicate nanofibers in poly(vinyl alcohol) solution," Soft Matter, vol. 1, no. 5, pp. 372-377, 2005.

[17] K. Yamamoto, H. Otsuka, S. Wada, and A. Takahara, "Surface modification of aluminosilicate nanofiber 'Imogolite"' Chemistry Letters, no. 11, pp. 1162-1163, 2001.

[18] A. Nakano, N. Teramoto, G. Chen, Y. Miura, and M. Shibata, "Preparation and characterization of complex gel of Type I collagen and aluminosilicate containing imogolite nanofibers," Journal of Applied Polymer Science, vol. 118, no. 4, pp. 22842290, 2010.

[19] N. Jiravanichanun, K. Yamamoto, K. Kato et al., "Preparation and characterization of imogolite/DNA Hybrid Hydrogels," Biomacromolecules, vol. 13, no. 1, pp. 276-281, 2012. 
[20] J. Alemán, A. V. Chadwick, J. He et al., "Definitions of terms relating to the structure and processing of sols, gels, networks, and inorganic-organic hybrid materials (IUPAC recommendations 2007)," Pure and Applied Chemistry, vol. 79, no. 10, pp. 1801-1829, 2007.

[21] W. Markgraf, R. Horn, and S. Peth, "An approach to rheometry in soil mechanics-Structural changes in bentonite, clayey and silty soils," Soil and Tillage Research, vol. 91, no. 1-2, pp. 1-14, 2006.

[22] E. L. Bakota, Y. Wang, F. R. Danesh, and J. D. Hartgerink, "Injectable multidomain peptide nanofiber hydrogel as a delivery agent for stem cell secretome," Biomacromolecules, vol. 12, no. 5, pp. 1651-1657, 2011.

[23] J. Karube, K. Nakaishi, H. Sugimoto, and M. Fujihira, "Electrophoretic behavior of imogolite under alkaline conditions," Clays and Clay Minerals, vol. 40, no. 6, pp. 625-628, 1992.

[24] Y. Horikawa, "Electrokinetic phenomena of aqueous suspensions of allophane and imogolite," Clay Science, vol. 4, no. 6, pp. 255-263, 1975. 

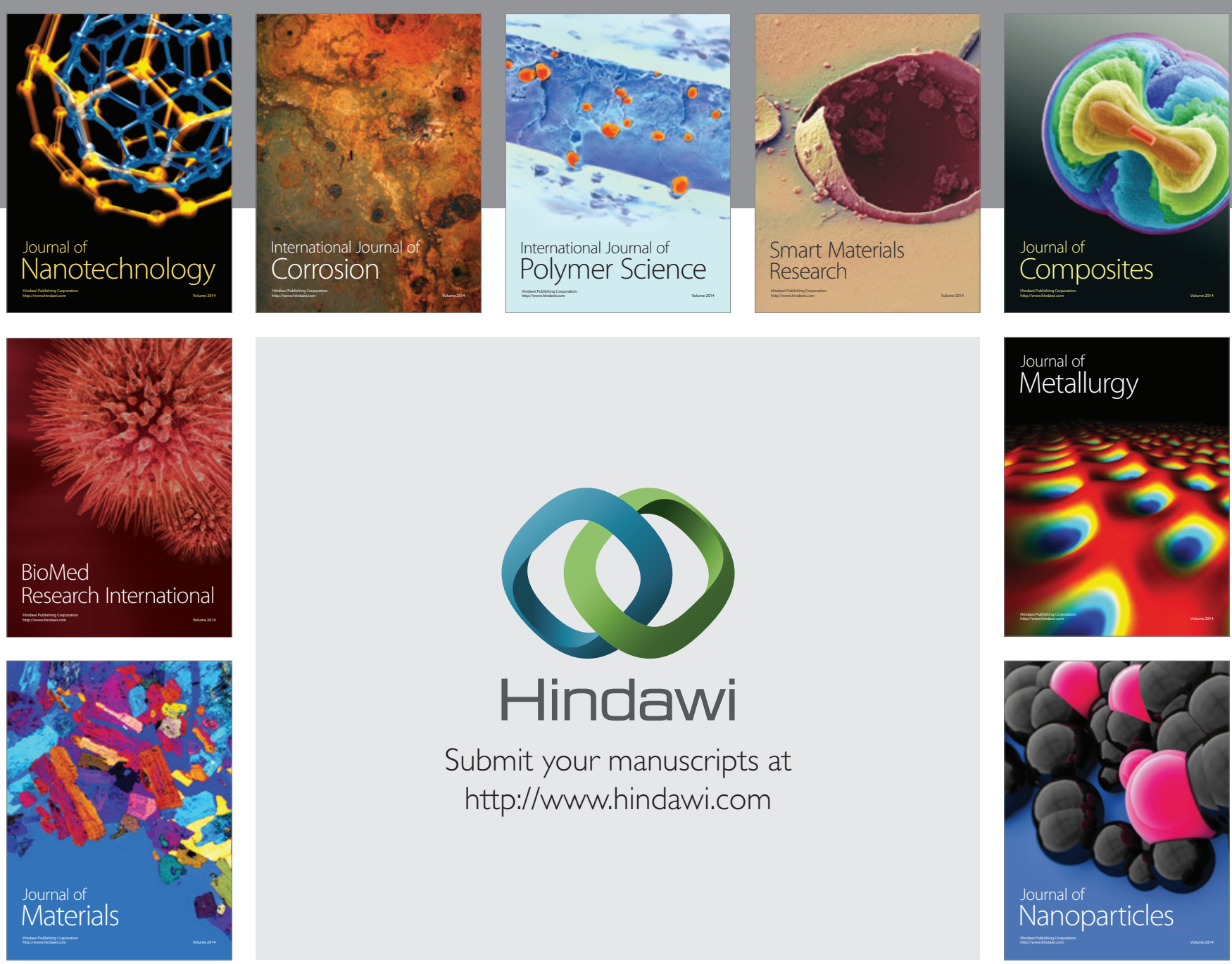

Submit your manuscripts at http://www.hindawi.com
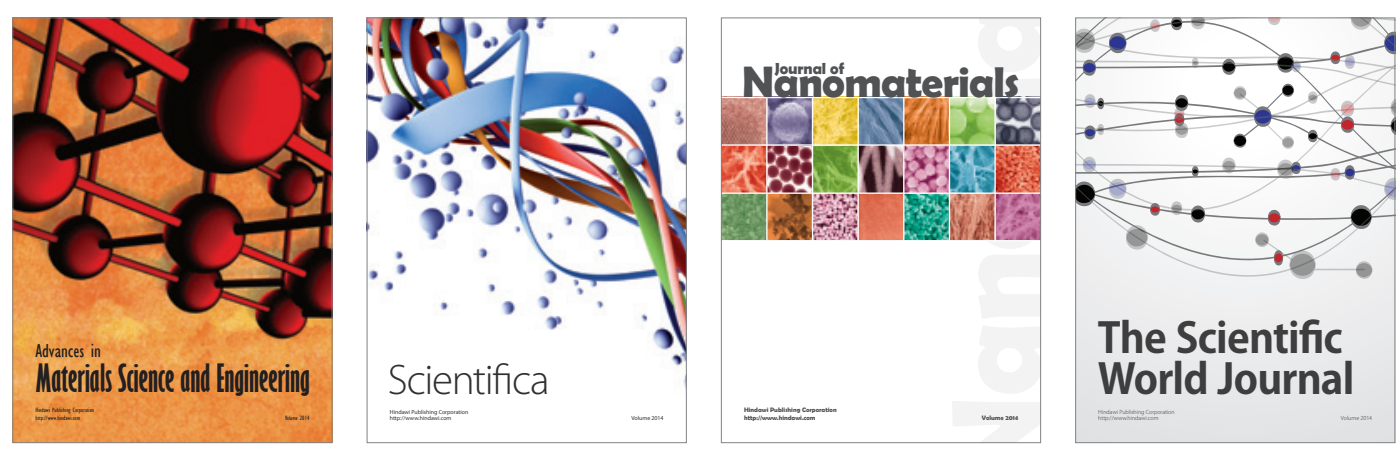

\section{The Scientific World Journal}
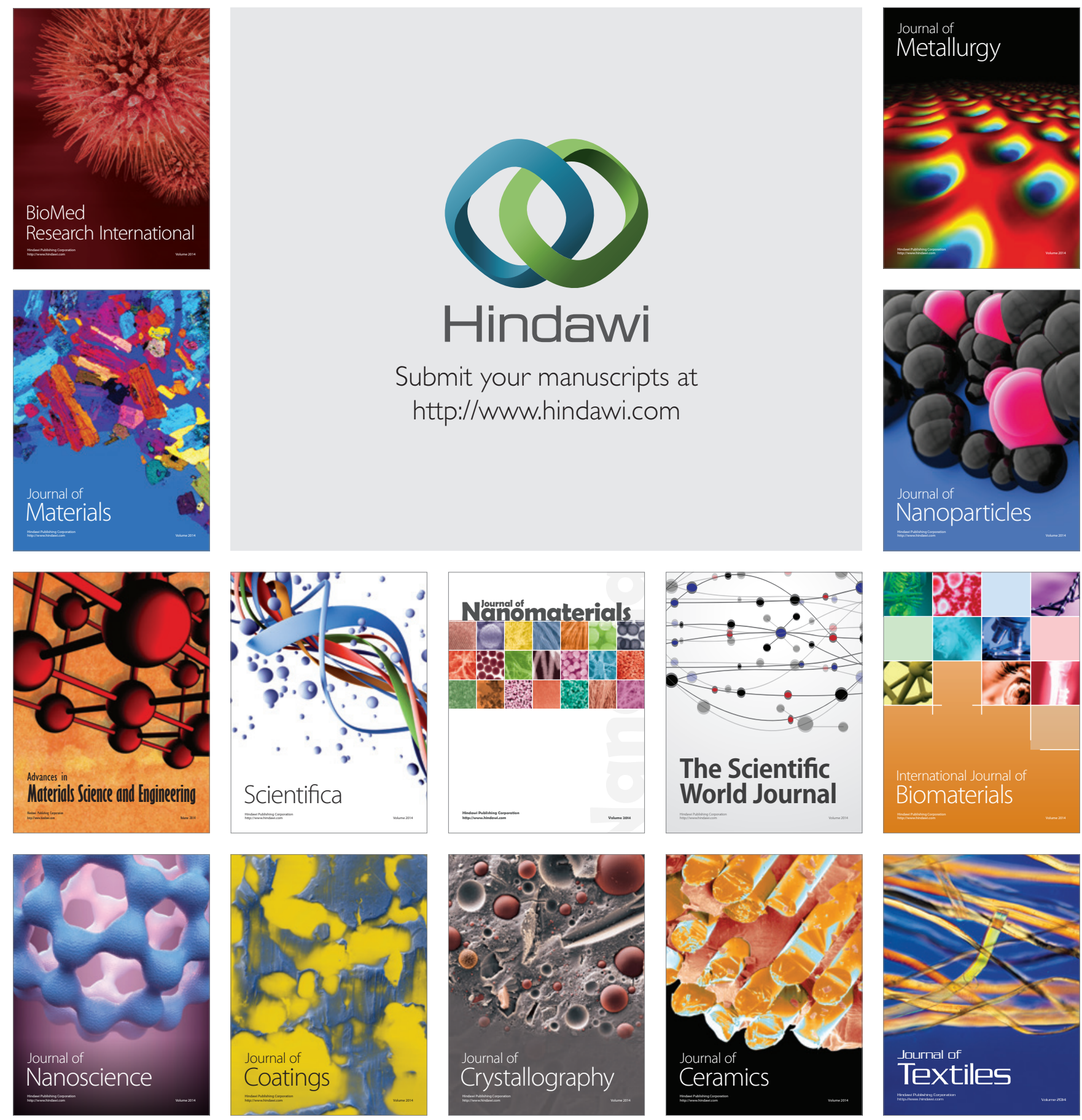